\title{
Rhaphiostylis minima Jongkind (Icacinaceae), a new liana species from Ivory Coast \& Liberia
}

\author{
Carel C.H. JONGKIND \\ Botanic Garden Meise, Nieuwelaan 38, 1860 Meise, Belgium. \\ E-mail: carel.jongkind@kpnmail.nl
}

\begin{abstract}
A new species of Rhaphiostylis, R. minima sp. nov. from Liberia and Ivory Coast, is described and illustrated here. It is characterised by its comparatively small size, an ovate to lanceolate leaf blade with long drip tip and a partly glabrous ovary that is in shape in between those of $R$. elegans Engl. and $R$. preussii Engl. Rhaphiostylis elegans is lectotypified and illustrated here.
\end{abstract}

Keywords. Rhaphiostylis, tropical forest, taxonomy, conservation.

Jongkind C.C.H. 2015. Rhaphiostylis minima Jongkind (Icacinaceae), a new liana species from Ivory Coast \& Liberia. European Journal of Taxonomy 138: 1-8. http://dx.doi.org/10.5852/ejt.2015.138

\section{Introduction}

Rhaphiostylis is an Icacinaceae genus of $c a .10$ liana species endemic to tropical Africa (Boutique 1960, Villiers 1973a, 1973b). Only 4 species were known from the Upper Guinean flora subregion (the closed forest from Senegal to Togo) where the new species was discovered, $R$. beninensis (Hook.f. ex Planch.) Planch. ex Benth., R. cordifolia Hutch. \& Dalziel, $R$. ferruginea Engl. and $R$. preussii Engl. (Hepper 1958: 638; Hawthorne \& Jongkind 2006: 346).

In 2013 a small Rhaphiostylis climber with glabrous leaves and branches was found flowering and fruiting in the evergreen forest in the south-east of Liberia. With the small and slender leaves with a long drip tip it is already at first sight different from $R$. preussii. Rhaphiostylis preussii is the only other Rhaphiostylis with glabrous leaves often found in the undergrowth in that forest area. Later it became clear that the shape and indumentum of the ovary is also distinct (Fig. 1F). In Rhaphiostylis the leaf shape and the indumentum of the ovary are important characters for identification of the species (Hepper 1958). The new species, $R$. minima sp. nov., most resembles $R$. elegans Engl. from Cameroon, being also a smaller liana with more or less similar leaves. The new species differs from $R$. elegans by its less stretched and more hairy ovary (Fig. 1F, Table 1). Moreover, there exists also a large geographical gap between the two. The here illustrated flower of $R$. elegans shows the stretched ovary with a long narrow middle part, while the ovaries of the two $R$. preussii flowers, from Ivory Coast and Gabon, have only a narrow constriction. The ovary of $R$. minima sp. nov. is in shape and indumentum in between $R$. elegans and $R$. preussii. The ovary of the only other Rhaphiostylis species from Upper Guinea with glabrous leaves and branches, $R$. beninensis, is in shape and size more or less equal to the one of $R$. preussii but it is glabrous or almost so (Villiers 1973a: 35). The flower of $R$. preussii, illustrated by Villiers (1973a: 35) after Le Testu 7491 from Gabon, is similar to that of the specimens illustrated here. 
The new species is named here R. minima sp. nov., it being the smallest species in the genus. All specimens are small climbers only a few meters high, much smaller than all other Rhaphiostylis species from Upper Guinea. Except for $R$. preussii, the hairy $R$. cordifolia is the only other Rhaphiostylis species found in the same evergreen forests. Rhaphiostylis beninensis and $R$. ferruginea are growing in drier forest types like semi-deciduous forest (Hawthorne \& Jongkind 2006: 3).

In a table (Table 1) all Rhaphiostylis species with glabrous leaves and branches from Upper Guinea and R. elegans are compared.

When preparing the Icacinaceae issues of the Floras of Cameroon and Gabon, Villiers could not find type material of R. elegans and could not place it (Villiers 1973a: 41). The original description (Engler 1909: 184) was based on fruiting material only and the flowers were never described, this made it difficult to understand the taxon. In 1986 a duplicate of the destroyed holotype was found in the MO herbarium by Al Gentry and Duncan Thomas (noted on the sheet). During the research on the new species it was possible to match this isotype of $R$. elegans in herbaria with other specimens. In this publication an illustration is included from a newly identified flowering specimen (Fig. 1).

In the fresh flowers of $R$. preussii and $R$. beninensis the flat filaments touch each other along the edge and together they close around the ovary from their base to about half their length (Figs 2, 3). It is likely that the stamens of $R$. minima sp. nov. and those of other species in the genus share this character because they also share the special shape of the filaments.

\title{
Materials and Methods
}

The new species was studied and collected in 2013 and 2014 by the author in the forest in the southeast of Liberia. The BR, K, P and WAG herbaria were searched for additional specimens of the new species and $R$. elegans. The herbarium, where the specimens are located, is indicated by the international code (herbarium acronym) registered in Index Herbariorum (Thiers continuously updated). Preliminary assessments of the IUCN Red List categories of threat were performed using the IUCN criteria and the Royal Botanic Gardens Kew website http://geocat.kew.org.

\section{Results}

\author{
Order "unplaced" (Kårehed 2001) \\ Family Icacinaceae Miers
}

Genus Rhaphiostylis Planch. ex Benth.

\section{Key to the species in Upper Guinea (forest area west of Nigeria)}

1. Leaves and twigs of plant almost glabrous

- Leaves and twigs of plant densely appressed or erect hairy, at least on the young parts .................... 4

2. Ovary for most of its surface, and the fruit around the base of the style, hairy................................. 3

- Ovary glabrous or with a small patch of hairs on top, fruit glabrous

R. beninensis (Hook.f. ex Planch.) Planch. ex Benth.

3. Constricted middle of the ovary glabrous. All leaves with drip tip $1.5-3 \mathrm{~cm}$ long. Slender liana up to $4 \mathrm{~m}$ high .....

R. minima sp. nov.

- Constricted middle of the ovary hairy. Drip tip on leaves, if present, shorter. Usually a larger liana.

R. preussii Engl. 
4. Leafbase rounded to cordate. Flower pedicel up to $3 \mathrm{~mm}$ long. In evergreen forest......

R. cordifolia Hutch. \& Dalziel

- Leafbase cuneate or obtuse. Flower pedicel 6 to $9 \mathrm{~mm}$ long. Mainly in semideciduous forest R. ferruginea Engl.

\author{
Rhaphiostylis minima Jongkind sp. nov. \\ urn:lsid:ipni.org:names:77150009-1 \\ Table 1, Figs 1D-G, 2
}

\title{
Diagnosis
}

Slender woody liana up to $4 \mathrm{~m}$ high, resembling $R$. elegans Engl. from Cameroon in leafshape. Differing from $R$. elegans in the first place by its shorter and more hairy ovary, $2.5-3 \mathrm{~mm}$ versus $3.5-4 \mathrm{~mm}$.

\section{Type}

IVORY COAST. $c a .140 \mathrm{~km} \mathrm{~N}$ of Tabou, crossing Hana River, on the way to Taï, fl., 10 Oct. 1963, $W$. de Wilde 1061 (holo-: WAG; iso-: BR, K n.v.)

\section{Description}

Slender woody liana going up to 3-4 $\mathrm{m}$ high. Leaves alternate, glabrous; slender petiole 2-3 $\mathrm{mm}$ long; blade ovate to lanceolate, $5-10 \mathrm{~cm}$ long and $1.5-3.5 \mathrm{~cm}$ wide, papery, midrib impressed above, 3 or 4 pairs of main laterals of which the first are often long and ascending, margin entire, base rounded, apex long acuminate, up to $3 \mathrm{~cm}$ long with a spathulate tip. Inflorescences fasciculate, supra-axillary with 1-3 flowers. Flowers bisexual; pedicel 2-4 mm long; calyx 5 lobed, lobes about $1 \mathrm{~mm}$ long, puberulous; petals 5, ca. $5 \mathrm{~mm}$ long, valvate, free, glabrous. Stamens 5, glabrous; filaments subulate, gradually narrowing to filiform above, about $4 \mathrm{~mm}$ long, alternipetalous; anthers $c a .1 \mathrm{~mm}$ long. Ovary $2.5-3 \mathrm{~mm}$ high, hairy on the lower $1 / 2$ and at the top, almost glabrous on the narrow part in between; style $3.5-4 \mathrm{~mm}$ long, excentric but erect. Fruit 2-lobed, flattened through the longitudinal axis, fleshy with thin exocarp, smooth and glabrous, but conspicuously hairy on and around the base of the persistent style; endocarp woody, reticulate, about $1.5 \mathrm{~cm}$ wide and $1 \mathrm{~cm}$ high.

\section{Distribution and habitat}

South-east Liberia and south-west Ivory Coast below $250 \mathrm{~m}$ altitude. In the shade of evergreen forest with a rainfall of more than $2200 \mathrm{~mm}$ a year and a weak dry season.

\section{Additional material examined}

IVORY COAST. Entre Niebe et Bihoué, fl., 9 Aug. 1962, Jangoux 401 (BR).

LIBERIA. East of Greenville-Zwedru road, fl., fr., 23 Sep. 2013, Jongkind 12109 (BR, MO, P); West of Sapo National Park, 15 Sep. 2013, Jongkind 12321 (BR), Jongkind 12322 (WAG); West of Greenville, 18 Sep. 2013, Jongkind 12323 (BR); North of Sapo National Park, 27 Sep. 2013, Jongkind 12324 (BR); Ca. $50 \mathrm{~km}$ east of Greenville, 10 Mar. 2014, Jongkind 12361 (BR), 11 Mar. 2014, Jongkind 12381 (WAG).

\section{Conservation status}

The "Extent of Occurrence" (EOO) is 6,056 km² and the "Area of Occupancy" (AOO) is $32 \mathrm{~km}^{2}$, the EOO counts as "Vulnerable" and the EOO counts as "Endangered". The AOO is based on a cell width of $2 \mathrm{~km}$. None of the 9 specimens was collected in a protected area, but it is very likely that the species occurs in Sapo National Park in Liberia, as this protected area is completely included in the species EOO. The plant and its flowers are not conspicuous, so it is probably more common than what the few collections suggest. However, looking at all the economical development planned and in progress in this 


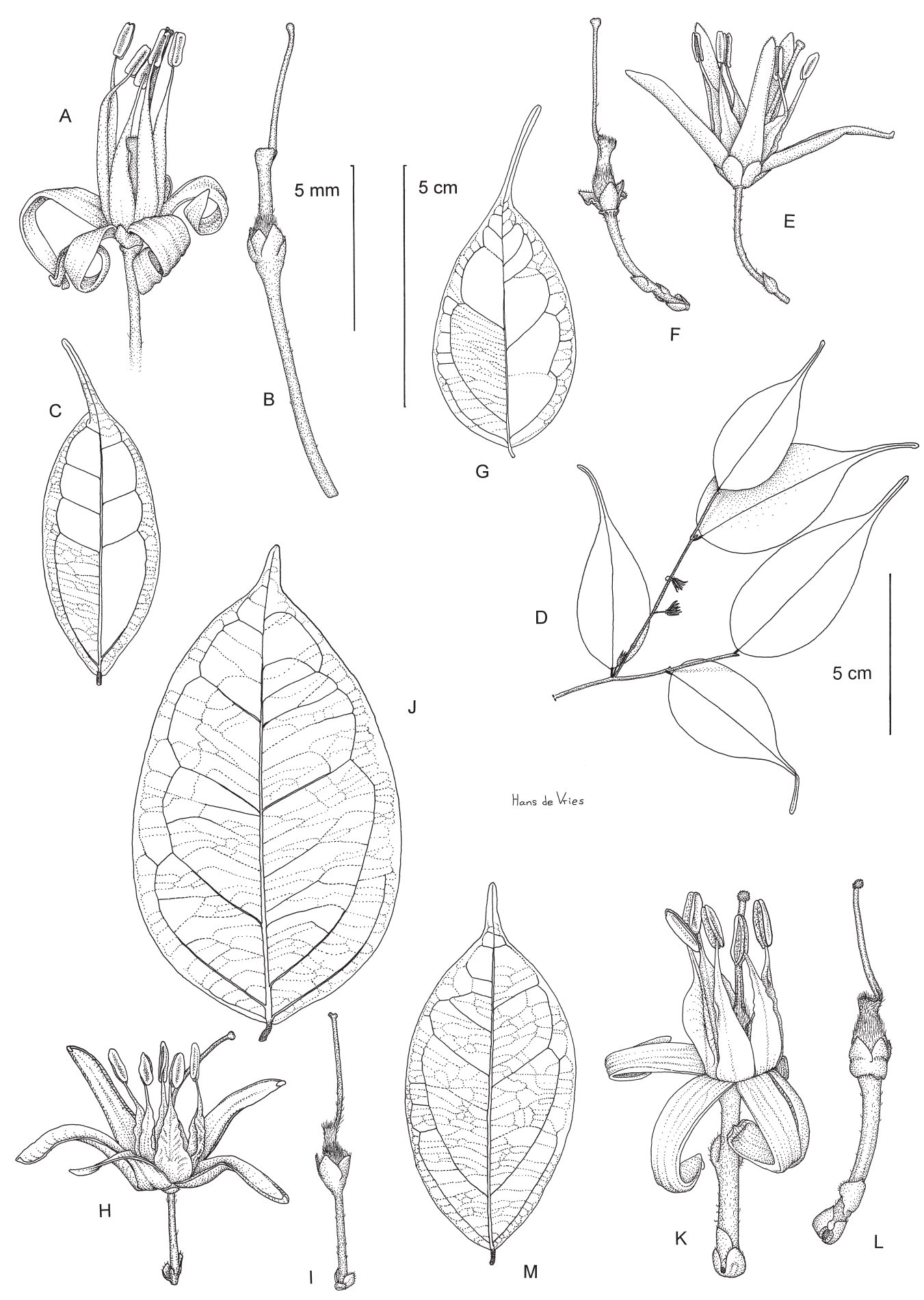

Fig. 1. A-C. Rhaphiostylis elegans Engl. A. Flower B. Flower without petals and stamens. C. Leaf. D-G. Rhaphiostylis minima sp. nov. D. Branch with flowers. E. Flower. F. Flower without petals and stamens. G. Leaf. H-M. Rhaphiostylis preussii Engl. H. Flower. I. Flower without petals and stamens. J. Leaf. K. Flower. L. Flower without petals and stamens. M. Leaf. All flowers are on the same scale (scale bar with B) and all single leaves too (scale bar with G). A-C from Tchouto \& Elad 3310 (WAG), D-G from W.de Wilde 1061 (WAG), H-J from Beentje 1353 B from Ivory Coast (WAG), K-M from Breteler 14204 from Gabon (WAG). Drawn by Hans de Vries. 
Table 1. Main differences between Rhaphiostylis beninensis, $R$. elegans, $R$. minima sp. nov. and $R$. preussii.

\begin{tabular}{|l|c|c|c|c|}
\hline & R. beninensis & R. elegans & R. minima sp.nov. & R. preussii \\
\hline $\begin{array}{l}\text { Length when } \\
\text { fertile }\end{array}$ & $>15 \mathrm{~m}$ & $5-10 \mathrm{~m}$ & $3-4 \mathrm{~m}$ & $>10 \mathrm{~m}$ \\
\hline Leaf apex & short acuminate & long driptip 1.5-3 cm & long driptip 1.5-3 cm & acuminate \\
\hline Ovary shape & $\begin{array}{c}1.5-2 \mathrm{~mm} \text { high, short } \\
\text { constriction between } \\
\text { lower part and top }\end{array}$ & $\begin{array}{l}3.5-4 \mathrm{~mm} \text { high, with } \\
\text { long constricted part }\end{array}$ & $\begin{array}{c}2.5-3 \mathrm{~mm} \text { high, shape } \\
\text { in between } R . \text { preussii } \\
\text { and } R \text {. elegans }\end{array}$ & $\begin{array}{c}1.7-2.5 \mathrm{~mm} \text { high, } \\
\text { short constriction } \\
\text { between lower part } \\
\text { and top }\end{array}$ \\
\hline $\begin{array}{l}\text { Ovary } \\
\text { indumentum }\end{array}$ & $\begin{array}{c}\text { glabrous or only } \\
\text { hairy on top }\end{array}$ & $\begin{array}{c}\text { only lower } \\
\text { ca. } 1 / 3 \text { hairy }\end{array}$ & $\begin{array}{c}\text { hairy on the lower half } \\
\text { and at the top, almost } \\
\text { glabrous on the narrow } \\
\text { part in between }\end{array}$ & $\begin{array}{c}\text { completely hairy } \\
\text { or only glabrous } \\
\text { around the base }\end{array}$ \\
\hline
\end{tabular}

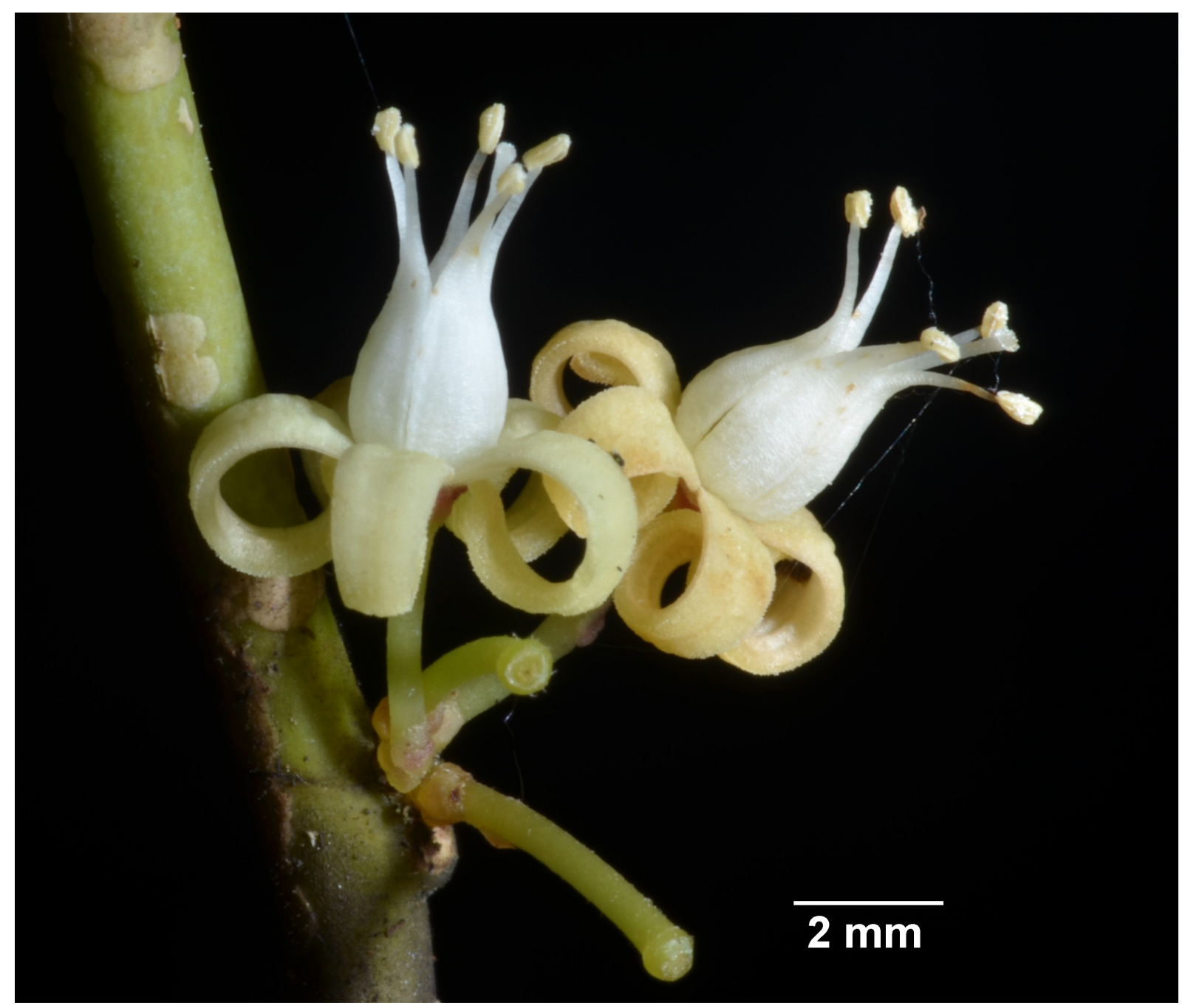

Fig. 2. Rhaphiostylis preussii Engl. showing flowers with the flattened filaments closing around the ovary while the petals are bending down. Photograph by Ehoarn Bidault (Missouri Botanical Garden) from Bidault $786(\mathrm{MO})$ from Gabon. 


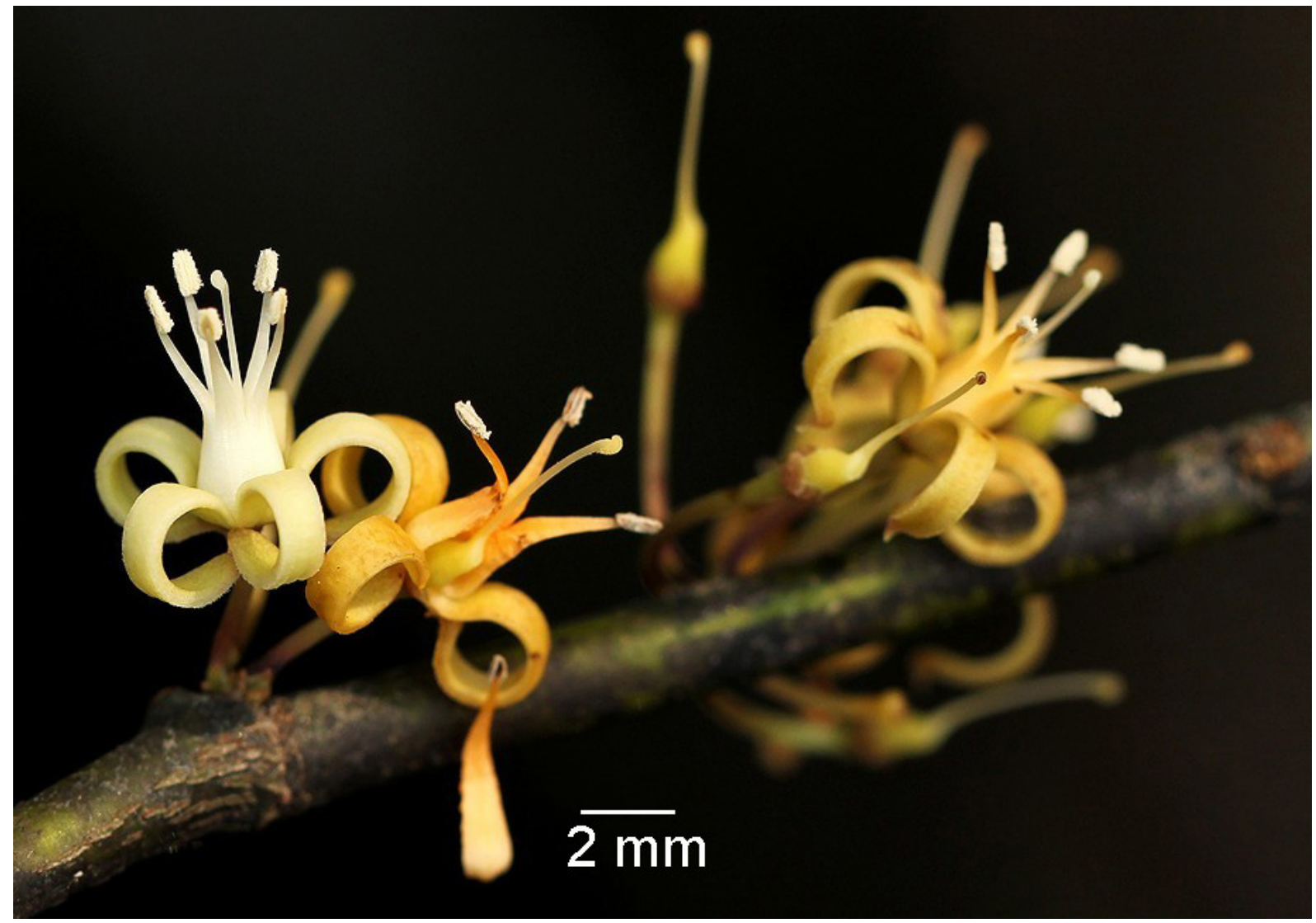

Fig. 3. Rhaphiostylis beninensis (Hook.f. ex Planch.) Planch. ex Benth., like Fig. 2, but also showing ovary and style in older flowers. Photograph by Bart Wursten from Boyekoli Ebale Botany 785 (BR) from Congo Kinshasa (copyright Botanic Garden Meise).

part of Liberia, and while it is not sure that the species grows in a protected area, "Vulnerable" should be the correct status for the moment (B1 \& B2 ab(iii), IUCN 2015).

\section{Remarks}

All specimens cited under the new species were collected after the publication of the Icacinaceae in the Flora of West Tropical Africa (Hepper 1958).

The leaves of seedlings of Rhaphiostylis beninensis and $R$. preussii may resemble those of mature $R$. minima sp. nov.

\section{Rhaphiostylis elegans Engl.}

(Fig. 1A-C)

Botanische Jahrbücher für Systematik, Pflanzengeschichte und Pflanzengeographie 43: 184 (Engler 1909). - Type: Cameroon, Bipindi, fr., Jan. 1908, Zenker 3615 (holo-: B destroyed; lecto-: MO [MO260675] designated here).

\section{Additional material examined}

CAMEROON. Between Kienke river and km 7 on Kribi-Ebolowa road, fr., 17 Oct. 1969, Bos 5535 (BR, K, P, WAG); 7.5 km from Kribi, few km N. of Ebolowa road, fl. buds, 24 Aug. 1970, Bos \& 


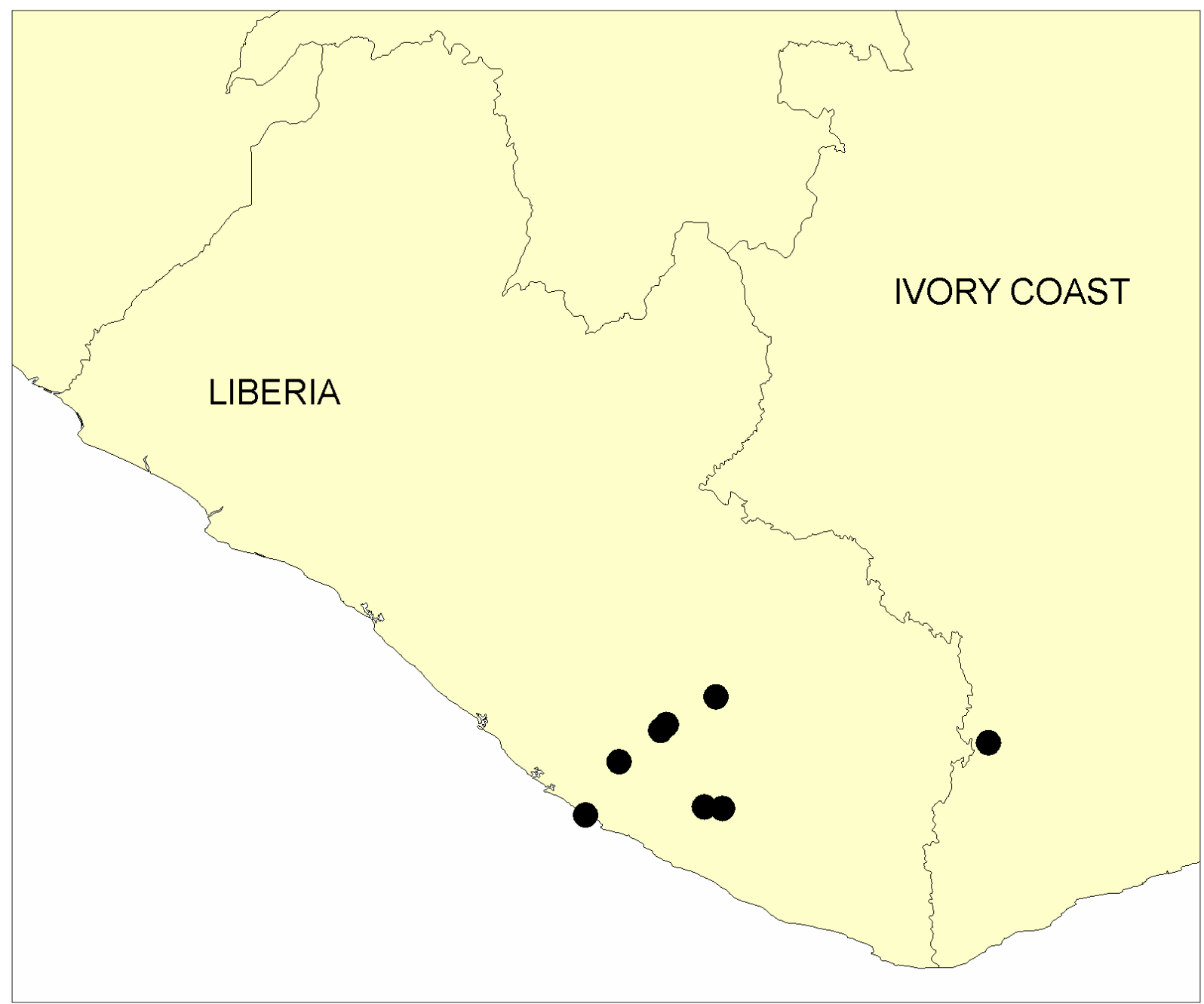

Fig. 4. Distribution map of Rhaphiosylis minima sp. nov.

Breteler 7257 (BR, K, P, WAG); Bidou, Nkol Mbouda on "Mont d'Elephant”, fl., 16 Oct. 2001, Tchouto Mbatchou \& Elad 3310 (WAG).

\section{Remarks}

Specimens of Rhaphiostylis elegans key out as R. preussii with the Flore du Gabon (Villiers 1973a) and Flore du Cameroun (Villiers 1973b). According to notes in the WAG herbarium there should be a duplicate specimen of the type in Kew but I could not find it.

\section{Acknowledgements}

I am grateful to Hans de Vries for preparing the drawing, and I also want to thank Ehoarn Bidault and Bart Wursten for the use of their photographs.

\section{References}

Boutique R. 1960. Icacinaceae. In: Robyns W., Staner P., Demaret F., Germain R., Gilbert G., Hauman L., Homès M., Jurion F., Lebrun J., Vanden Abeele M. \& Boutique R. (eds) Flore du Congo Belge et du Ruanda-Urundi: vol. 9. Institut National pour l'Étude Agronomique du Congo belge, Brussels. 
Engler E. 1909. Icacinaceae africanae. Beiträge zur Flora von Afrika XXXIV. Botanische Jahrbücher für Systematik, Pflanzengeschichte und Pflanzengeographie 43: 179-188.

Hawthorne W.D. \& Jongkind C.C.H. 2006. Woody plants of Western African forests, A guide to the forest trees, shrubs and lianes from Senegal to Ghana. Royal Botanic Gardens, Kew.

Hepper F.N. 1958. Icacinaceae. In: Keay R.W.J. (ed.) Flora of West Tropical Africa, $2^{\text {nd }}$ Ed. Vol. 1 (2): 636-644. Crown Agents for Oversea Governments and Administrations, London.

IUCN 2015. IUCN Red List Categories and Criteria: Version 3.1. Prepared by the IUCN Species Survival Commission. IUCN, Gland, Switzerland/Cambridge, U.K.

Kårehed J. 2001. Multiple origin of the tropical forest tree family Icacinaceae. American Journal of Botany 88 (12): 2259-2274. http://dx.doi.org/10.2307/3558388

Thiers B. continuously updated. Index Herbariorum: A global directory of public herbaria and associated staff. New York Botanical Garden's Virtual Herbarium [online]. New York Botanical Garden's Virtual Herbarium, New York. Available from http://sweetgum.nybg.org/ih/ [accessed 9 Jan. 2015].

Villiers J.-F. 1973a. Icacinacées. In: Aubréville A. \& Leroy J.-F. (eds) Flore du Gabon 20. Muséum national d'Histoire naturelle, Paris.

Villiers J.-F. 1973b. Icacinacées. In: Aubréville A. \& Leroy J.-F. (eds) Flore du Cameroun 15. Muséum national d'Histoire naturelle, Paris.

Manuscript received: 10 February 2015

Manuscript accepted: 14 July 2015

Published on: 22 September 2015

Topic editor: Thomas Janssen

Desk editor: Natacha Beau

Printed versions of all papers are also deposited in the libraries of the institutes that are members of the EJT consortium: Muséum National d'Histoire Naturelle, Paris, France; National Botanic Garden of Belgium, Meise, Belgium; Royal Museum for Central Africa, Tervuren, Belgium; Natural History Museum, London, United Kingdom; Royal Belgian Institute of Natural Sciences, Brussels, Belgium; Natural history Museum of Denmark, Copenhagen, Denmark 